\title{
Nostalgia, Nationalism and Notability: The Success of Skyfall
}

\author{
SARAH KELLEY, University of Bristol
}

\begin{abstract}
2012 saw the release of what has since been branded 'the most successful British film to date': Skyfall broke box office records by making $£ 94$ million in the first 40 days of its release. The positive reception from film critics would have undoubtedly gone some way to attracting patrons to its cinema run, however, the overwhelming commercial success of Skyfall indicates that there were more hooks at play here, amongst the promotional campaign for the film. This article argues that strong themes of nostalgia, nationalism and notability (of the cast and crew), present throughout the marketing and preview literature for Skyfall, played a significant part in generating audience interest for the film. Through textual analysis of a variety of artefacts circulated in anticipation of the film's release, this article aims to explore how these three themes engaged with the audience and helped to ensure a successful box office run for Skyfall.
\end{abstract}

\section{KEYWORDS}

Analysis, film, promotion, Skyfall, success.

\section{Introduction}

'And we're back': the words used by an enthralled Mark Kermode (2012) in his review of the most recent instalment in the Bond movie franchise, Skyfall (Sam Mendes, 2012). Despite the commercial success of Skyfall's predecessor, Quantum of Solace (Marc Forster, 2008), the negative response it received from reviewers, who critiqued it for a lack strong themes and identity, meant that the latest Bond instalment was in danger of losing its audience. In contrast to the previous film (which Kermode dubbed 'Question of Sport' in mockery of its rather forgettable title), the producers of Skyfall needed to give the cinema-going public a good reason to pay to see their new attempt. In fact, it became the most successful British film to date by making $£ 94$ million at the box office within the first 40 days of its release and, importantly, it received the thumbs up from renowned movie critics such as Kermode. I will show here how they succeeded largely thanks to a carefully crafted marketing campaign. This article explores how strong themes of nostalgia, nationalism and notability (of the cast and crew) were used in the promotional material for Skyfall in order to ensure its commercial success.

My approach here draws on Barabara Klinger's idea of a cinematic 'histoire totale': an approach to documenting the impact of film by considering a variety of different sources outside of the actual film text. Klinger explains that 'A totalized perspective thus depicts how social forces invite viewers to assume positions, giving us a range of possible influences on spectatorship' (1997, 114). That is to say that one can look beyond the film itself in order to determine the reasons for its 
hugely positive reception. With this in mind, I have applied textual analysis to related artefacts from the build-up to the release of Skyfall in an attempt to present a neutral investigation, free from the opinions of secondary sources: a research ethic championed by Alex Clayton and Andrew Klevan, who write 'Most academic writing aims for a prose that is neutral, objective or informational' $(2011,2)$.

\section{Ephemera and Artefacts}

Phil Wickham argues that '[e]phemera can allow an insight into life as it was lived' $(2010,317)$. That is to say that the artefacts surrounding film, the items associated with films that are designed to infiltrate the audience's daily lives, can hold the key to revealing information on public feeling and action at the time. He goes on to write that, crucially, ephemera and artefacts give us a 'history without hindsight', which means that we can get a more accurate picture of what a film means to the audience at that time rather than anything written later, looking back on past events (ibid.). The Bill Douglas Cinema Museum is purpose built for this kind of ephemeral research, holding film artefacts from Marilyn Monroe soap dishes to Juno drinking cups.

The product endorsements used to promote Skyfall include a mixture of every day-use items such as Coca-Cola bottles and high end goods such as Omega watches and Bollinger champagne (see figure 1): the former endorsements promote the film to a wide audience and the latter links the character of James Bond with a certain class status, a trait with which the audience may aspire to associate themselves. The Bollinger endorsement, in particular, serves another important purpose in promoting the ideals of the film. It is a product, which has been regularly referenced in the films since the days of Sean Connery's Bond therefore it evokes a sense of nostalgia and sentimentality for the traditional features of the films, a theme at the centre of the marketing campaign for Skyfall, which capitalised on the 50th anniversary of the first Bond film, Dr. No (Terence Young, 1962). Examining Skyfall's pre-release artefacts in this way involves the use of textual analysis, a form of qualitative research, which is focused on 'the opinions and ideas' that are formed through the features of a text (Branston and Stafford 2005, 278).
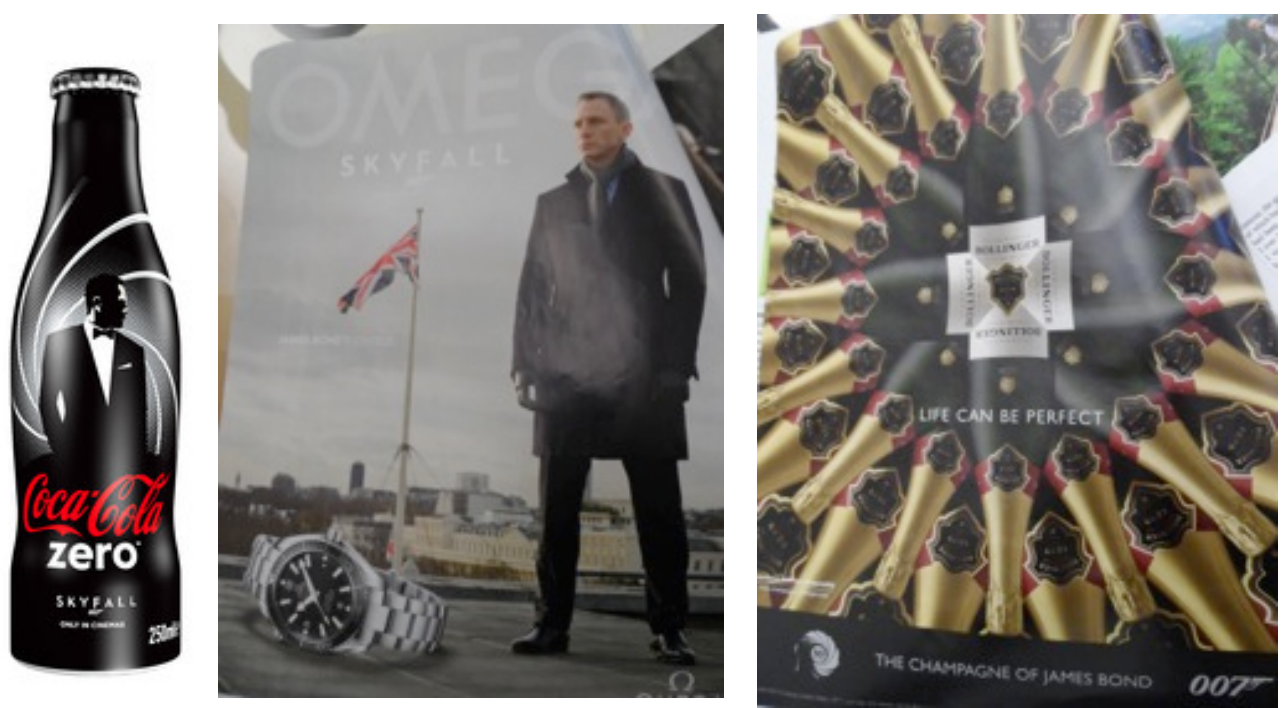

Figure 1: Coca-Cola, Omega and Bollinger, product endorsements for Skyfall 
Applying this analytical method to magazine articles, printed in the build-up to Skyfall's release, we can identify three themes that are consistently emphasised and intermingled in association with the film: nostalgia, nationality and notability. This article includes the analysis of two editions of Empire magazine. According to the Audit Bureau of Circulation (ABC) figures, this is one of the biggest players in the film magazine market, boasting an average monthly circulation figure of 160,067 (figure calculated for the first half of 2013). Empire is published in several countries around the world, including the United States. It is reasonable to assume that this is a prime outlet for the Skyfall producers to spread their themes in promotion of the new film, since Kate Kenski and Natalie Jomini Stroud explain 'the media plays an important role in generating public interest about a topic' $(2007,541)$. One of the Empire editions is a special Bond-themed publication, released in June 2012 and the other is an edition detailing certain scenes from Skyfall, released in October as part of the count down to the film's box office opening. To these one can not only apply textual analysis to its articles but also content analysis, a form of quantative research, which involves counting the use of words and phrases, which promote the three themes of nostalgia, nationality and notability (Branston and Stafford 2005, 278). This research provides insight into the expectations that were set up for the audience in the build-up to Skyfall's release and ultimately what influenced them to flock to cinemas in their millions.

\section{Nostalgia}

The Bond special edition of Empire magazine in June 2012 not only contained a lengthy article on Skyfall but also five separate articles on issues surrounding past Bond films: the title of each one beginning with 'Bond 50'. In this way, the 50th anniversary of the first Bond film not only acts as an easy-to-understand, simple-to-implement (just the mention of '50' suffices) promotional tool for Skyfall, with all the promise of a film that will honour the popular traditions of the Bond franchise, it was also of benefit to Empire magazine, which was willing to oblige with the 50th theme as its look back at five decades of films wouldn't have required a huge effort to source new material, yet was still likely to attract readership. It is, therefore, a winning situation for all. Empire's emphasis on the 50th anniversary meant that 22 of the 30 pages dedicated to Bond were about past films and were focused on conveying this nostalgic theme.

With this in mind, the Skyfall article itself also makes regular references to Bond films of the past: sixteen mentions in total. These are used to compare Skyfall to successful films of the past: 'Both Craig and Mendes have mentioned From Russia With Love [Terence Young, 1963] and Live and Let Die [Guy Hamilton, 1973] as touchstones [...]. There are hints also that this could prove to be the Goldfinger [Guy Hamilton, 1964] of the reboot era' (Jolin 2012, 58). These particular films are staples of the series and have all grossed between $\$ 80$ and $\$ 125$ million: huge successes of their time. In this way, the article implies that the audience can expect Skyfall to include the types of things they may have liked about these earlier films. 


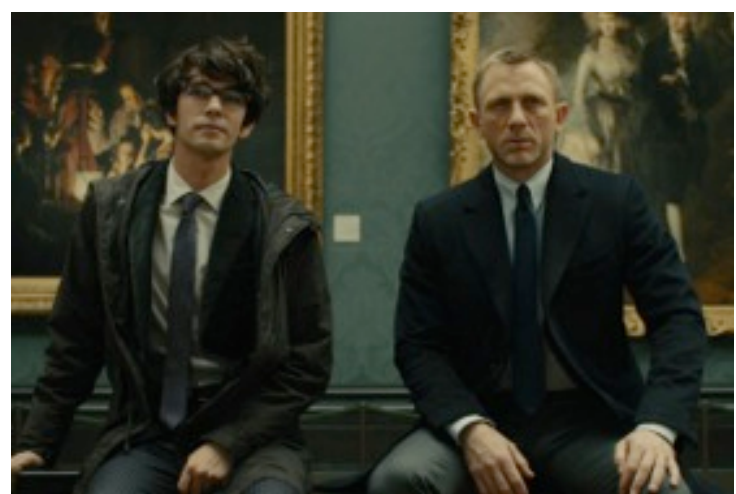

Figure 2: $Q$ and Bond in the trailer for Skyfall

The frequent mentions of these nostalgic influences on Skyfall also coincide nicely with the trailer released at this time, which draws the audience's attention to the return of some classic Bond conventions such as the inclusion of a Q character (last seen during Pierce Brosnan's run), whose uncharacteristic youth provokes humour when, after his introduction, Bond replies 'you must be joking' (see figure 2). In the June edition of Empire, references to the past also serve to distance Skyfall from the failures of the Bond series as exemplified in quotes such as '[The producers] have decided to snip off the dangling plot threads that had connected Casino Royale and Quantum of Solace. Skyfall is an all-new mission' (Jolin 2012, 57). In this article we can see that regular references to earlier films are made in such a way as to evoke the right kind of nostalgia for the reader and future audience: an appraisal for the popular moments in the series and the damning of instances when Bond has 'gone wrong'. The article from the October 2012 edition of Empire magazine also includes regular nostalgic references. There are 24 nods to past films, a significant amount of these are constituted by italicised descriptions of memorable moments in the earlier films (see figure 3). These instances of throwback mark the beginning of each new section of the article and continue the theme that Skyfall will acknowledge the elements that have made certain Bond films so popular.

Nostalgia is also evoked in this article through the use of photographs. We are presented with images of the iconic Aston Martin from Goldfinger and a vodka martini glass, which implies that

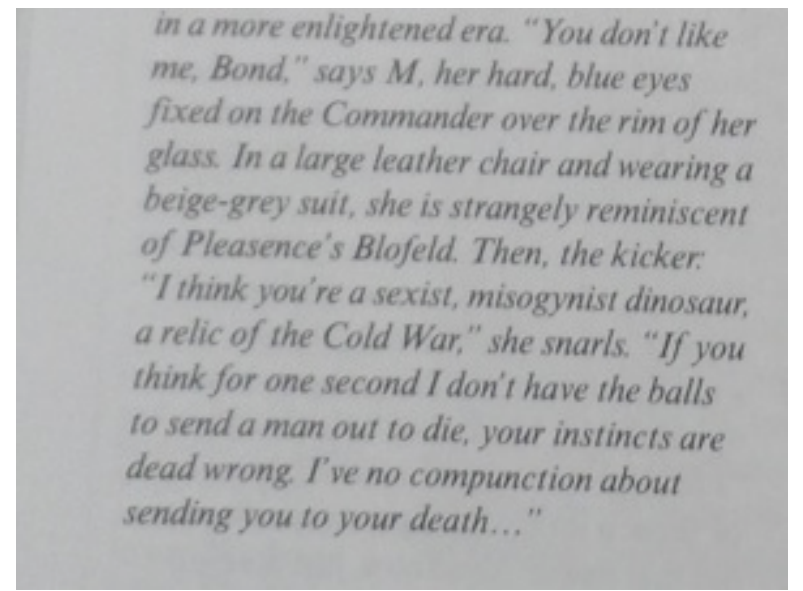

Figure 3: Memorable moment from Goldeneye in Empire, October 2012 

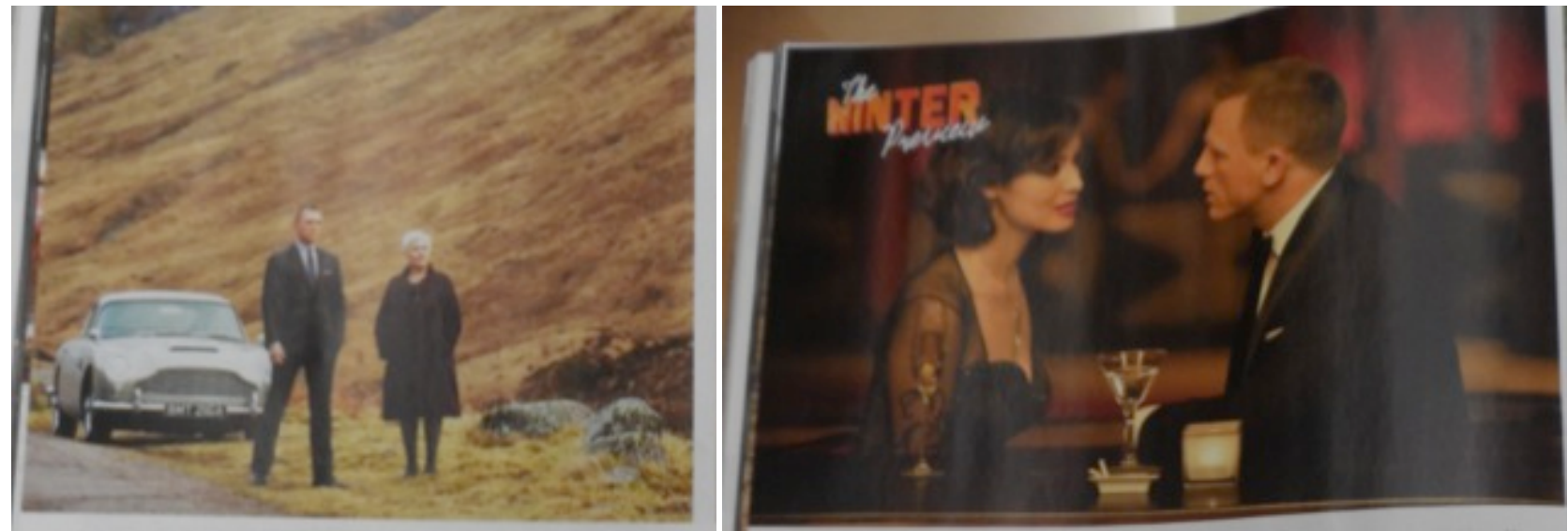

Figure 4: Left: Bond and M stand in front of the iconic Aston Martin; right: Bond and a vodka martini glass, Empire, October 2012

Skyfall will include the famous Bond line, 'Shaken, not stirred' (see figure 4). As Todd Gitlin explains, in print media photographs are particularly powerful in communicating a certain message and it is for this reason that they are chosen so carefully: 'Editors could choose among a range of photos from both their own photographers (if assigned) and the wire services; they chose this particular picture' (Gitlin 1980, 47). That is to say that there is always a significant reason behind a particular photo choice: in this case, with the film yet to be released, these particular screenshots from the film would have been made available to Empire by Skyfall's producers, as part of the promotional theme of nostalgia.

\section{Nationality}

Images in both articles also promote the theme of nationality. The Skyfall article in the June edition starts with a two-page spread of a London backdrop, complete with Big Ben and a union jack flying in the background (see figure 5). This nationalist scene is already familiar with the audience as the teaser trailer uses this image to accompany dialogue from a word association exercise that Bond undergoes in the film: we hear Bond prompted with the word 'country'; he responds 'England'. The October article includes a still (and accompanying mini-article) from the James Bond/Queen Elizabeth sketch, filmed for the London 2012 Olympics opening ceremony (see figure 5). These images make explicit Bond's identity as a British subject, serving his Queen and country.

The strong theme of nationalism here is most likely a response to the rise in Anglophilia as several events prior to Skyfall's production turned the world's attention to the British Isles. Beginning with the marriage of Prince William and Princess Catherine, a media frenzy surrounded their wedding day on 29th April 2011. The event was broadcast live worldwide and people travelled from other countries to catch a glimpse of the couple going into Westminster Abbey. This event demonstrated that traditional British ceremonies, such as a Royal Wedding, are highly valued by a global audience. This interest in events celebrating British heritage continued into 2012 when Queen Elizabeth II's Diamond Jubilee was marked by a concert at Buckingham Palace and a Thames Pageant in London. Shortly after this the Bond producers capitalised on the growing admiration for their character's home country by arranging for Daniel Craig, as Bond, to appear in the Olympics opening ceremony in July 2012. In this short sequence, Bond is taken out of his fictional world and portrayed as if he really is working for her Majesty as he reports to the Queen at Buckingham Palace. This scene linked Bond with British nationalism to such an extent that his image was later 
used in return to advertise the country to others in a campaign for VisitBritain (see figure 6). The article in the October edition of Empire magazine also includes five comments of a nationalist vein within its text, including references to how buoyed director Sam Mendes was by Team GB's performance at the Olympics and Skyfall's unprecedented use of a UK setting. This combination of images and text sets up the audience's expectations for a film that will have a strong British national identity.

\section{Notability}

The high-calibre cast and crew is a point that is emphasised throughout both articles. The October article refers to Judi Dench's honorary title of Dame but it is its comments on director, Sam Mendes, which reveal the notability of the people involved in Skyfall to be a rather clever promotional tool for the film. As a director known more for his moving dramas - American Beauty (1999), Revolutionary Road (2008) - than high-octane actions films (Skyfall is actually his first venture into this genre) it is rather puzzling as to why he was asked to work on the film, especially when Empire reveals that in order to complete the job he had to consult other directors: 'Mendes sought advice from a surprising source: the director of two Bourne movies. "I'm friends with Paul Greengrass", (Jolin 2012, 103). His hiring, it seems, is in fact more to do with his big name status, a director, with whom the audience is familiar and can trust considering his accolades listed in the June Empire article: 'As well as being an Oscar winner, an Olivier winner and now the $11^{\text {th }}$ director of James Bond, Sam Mendes, is also, it would seem, a master of understatement' (Jolin 2012, 54). Mendes' involvement seems to be part of a theme of notability in which the Skyfall's producers' decision to employ an array of well-known, highly-regarded cast and crew is emphasised. The June Empire includes nine mentions of awards or prolific achievements gained by people involved in Skyfall including comments on cast members Judi Dench and Javier Bardem as Oscar winners and Albert Finney and Ralph Fiennes as Oscar nominees.

\section{Conclusion}

Analysing the Empire magazine issues has led me to accredit Skyfall's commercial success to a promotional agenda that balances three key themes, each tapping into populist thought. In keeping with James Chapman, Mark Glancy and Sue Harper's opinion that 'the film historian focuses on the cultural, aesthetic, technological and institutional contexts of the medium' $(2007,1)$, the reasons for

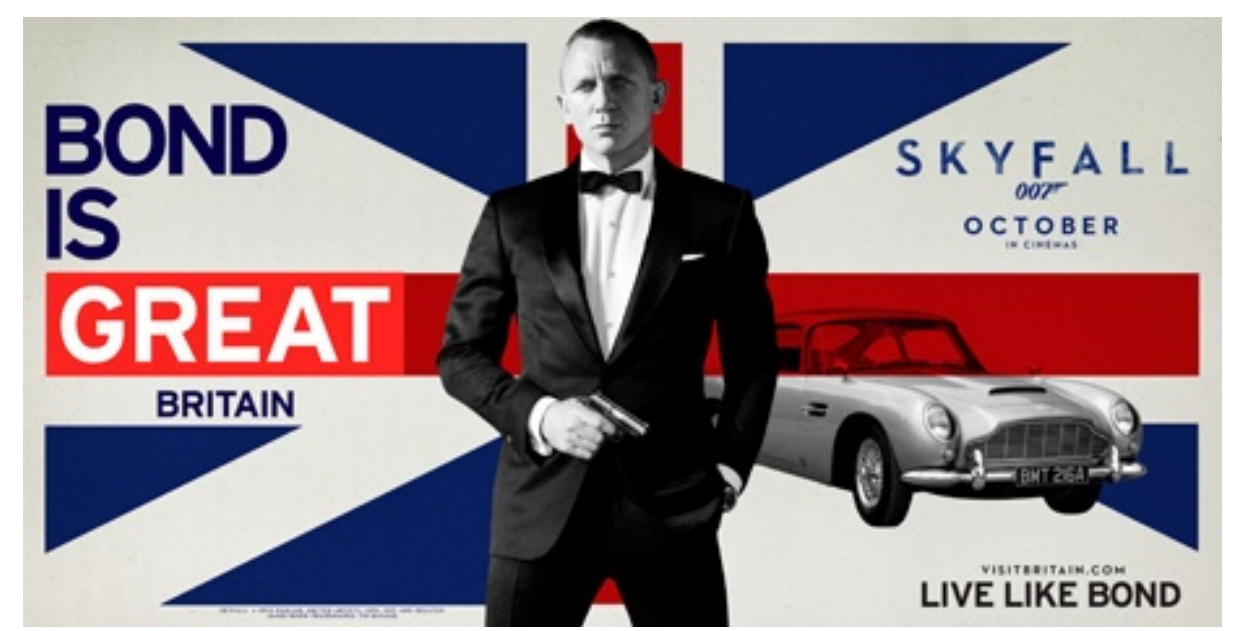

Figure 6: Image used by VisitBritain to promote the country to potential tourists 
the success of these themes in hooking the audience can be realised by linking them with various contextual factors. Firstly, the Bond series has lasted such a long time with older films still being shown on television today: there is clearly widespread appreciation for the conventions, which the nostalgia theme acknowledges. Secondly, the timing of the film, its release after favourable national events such as the Queen's jubilee and the London 2012 Olympics, meant that it could really play up the British national identity of Bond due to the popularity of the concept. Thirdly, it is well known that high-profile stars can bring in viewers to a film and Skyfall's emphasis on a notable cast and crew draws on this desirable feature.

\section{References}

Bordwell, D. and Thompson, K. (2004) Film Art: An Introduction, London: McGraw Hill

Branston, G. and Stafford, R. (2005) The Media Student's Book, London: Routledge

Chapman, C., Glancy, M. and Harper, S. (2007) 'Introduction', in C. Chapman, M. Glancy and S. Harper (eds), The New Film History, Houndsmills, Basingstoke: Palgrave Macmillan, pp. 1-10

Clayton, A. and Klevan, A. (2011) The Language and Style of Film Criticism, London: Routledge

Creeber, G. (1999) 'The Joy of Text?: Television and Textual Analysis', Critical Studies in

Television, 1(1), 81-88

Gitlin, T. (1980) The Whole World Is Watching: Mass Media in the Making and Unmaking of the New Left, Berkeley: University of California Press

Jolin, D. (2012) 'In Defence of the Realm' Empire, October

--- (2012) 'We've Been Expecting You, Mr Bond', Empire, October

Kenski, K and Stroud, N. J. (2007) 'From Agenda Setting to Refusal Setting' from Public Opinion Quarterly Vol. 71, No. 4, 538-559

Kermode, M. (2012) 'Mark Kermode Reviews Skyfall' from Kermode and Mayo's Film Review, [online audio], $26^{\text {th }}$ October. Accessible at http://www.bbc.co.uk/programmes/p0109stz. Accessed $1^{\text {st }}$ March 2013

Klinger, B. (1997) 'Film History Terminable and Interminable: Recovering the Past in Reception Studies,' from Screen, 38(2), 107-128

Kuhn, A. (2010) 'Snow White in 1930s Britain', Journal of British Cinema and Television, 7, 183199

Street, S. (2000) British Cinema in Documents, London: Routledge

Wickham, P. (2010) 'Scrapbooks, Soap Dishes and Screen Dreams: Ephemera, Everyday Life and Cinema History’, New Review of Film and Television Studies, 8(3), 315-30 


\section{Filmography}

American Beauty, 1999, directed by Sam Mendes, USA: DreamWorks Pictures

Casino Royale, 2006, directed by Martin Campbell, UK: Eon Productions; USA: United Artists

Dr. No, 1962, directed by Terence Young, UK: Eon Productions; USA: United Artists

From Russia With Love, 1963, directed by Terence Young, UK: Eon Productions; USA: United Artists

Goldeneye, 1995, Film, directed by Martin Campbell, UK: Eon Productions; USA: United Artists Goldfinger, 1964, directed by Guy Hamilton, UK: Eon Productions; USA: United Artists Live and Let Die, 1973, directed by Guy Hamilton, UK: Eon Productions; USA: United Artists Quantum of Solace, 2008, directed by Marc Forster, UK: Eon Productions; USA: United Artists Revolutionary Road, 2008, directed by Sam Mendes, USA: DreamWorks Pictures Skyfall, 2012, directed by Sam Mendes, UK: Eon Productions; USA: United Artists 